\title{
Ultrastructural Study of Programmed Cell Death of Tapetum in Panax ginseng
}

\author{
Byung-Kap Jeong*
}

Department of Biological Sciences, Kosin University, Pusan 606-701, Korea

Received March 26, 2009 / Accepted July 23, 2009

\begin{abstract}
Tapetum is the tissue in which nutrients are supplied to the developing microspore in angiosperm anther. At tetrad stage of microspore, the tapetal cells show maximum development, but they began to be degenerated by apoptotic programmed cell death (PCD) after sporopollenin accumulation in the pollen wall. The initial step of PCD was observed as vacuolar fusion. After that, cytoplasmic condensation and nuclear fragmentation followed. Lipid droplets are degenerated at a relatively late stage of PCD, and orbicular bodies are the last remains in tapetal cells. The cell wall was relatively resistant against vacuolar enzymes in tapetal cells; it was considered the last structure remaining during programmed cell death of tapetum in ginseng anther.
\end{abstract}

Key words : Tapetum, programmed cell death, ultrastructural study, cytoplasmic condensation, nuclear fragmentation

\section{Introduction}

Programmed cell death (PCD) is a successive processes of cell degeneration initiated by programme stored in nuclear DNA. Development, growth and differentiation of organisms are controlled by PCD accompanying structural, physiological and molecular changes of cell inclusions. PCD are induced by several different factors such as gravity [22,23], chemical stress [5,14,21], UV-induction [4], oxidative stress [2,20], heat shock [3], cold stress [18], Agrobacterium [11] and normal developmental processes [6,8,9,27,34-36].

Apoptosis-like cellular changes such as DNA degradation and nuclear fragmentation are observed in root of salt stressed plants [6]. DNA laddering is also detected in Arabidopsis root and BY2 cells of Zea mays [30], on the contrary, PCD without these typical structural changes are more common in plant cells [9].

Especially, nuclear DNA fragmentation, chromatin condentation, pigmentation concentration, membrane blebbing and formation of apoptotic bodies are key characteristics of PCD, and these structural changes are called apoptosis. Apoptosis has been known in animal cells rather than plant cells [16].

Chromatin condensation is the first step of apoptosis in animal cells, but invagination of plasma membrane and vesicle formation are known to be the first step in plant cells.

\footnotetext{
${ }^{*}$ Corresponding author

Tel : +82-51-990-2322, Fax : +82-51-911-2514

E-mail : bkjeong@kosin.ac.kr
}

The next step is known as chromatin condensation and appearances of membrane-bounded bodies. Cell walls are most stable and therefore they are the last degrading compartment in plant cells [1].

Despite of a lot of publications, principle mechanisms of programmed cell death of tapetal cells are still unidentified, even some proteinase are known to be involved in the degeneration of tapetum. Especially, serine proteinase LIM9 precursors are synthesized in the tapetal cells and then secreted to the locule, and which are supposed to initiate PCD of tapetal cells [7].

Pollen development has been studied in a lot of different plant species [12,13,19,24,31-34,39]. During this processes, degeneration of tapetum should be accompanied for supply of nutrients to developing microspores. But, tapetal PCD has not been well studied whether the structural changes of PCD is apoptotic, which is very common in animal cells, or followed other mechanism. Therefore the purpose of this research is to identify the initial changes of PCD, and structural processes of ginseng tapetal cells during microsporogenesis with transmission electron microscope.

\section{Materials and Methods}

Anthers of 4-years-old ginseng (Panax ginseng C.A. Meyer) were primary fixed in $1 \%$ paraformaldehyde $-2 \%$ glutaraldehyde in $100 \mathrm{mM}$ cacodylate buffer ( $\mathrm{pH} \mathrm{7.0)}$ for $2 \mathrm{hrs}$ at $4^{\circ} \mathrm{C}$. After rinsing in buffer for three times for 20 minutes each, secondary fixation was carried out in several changes (5 min, $10 \mathrm{~min}, 20 \mathrm{~min}$ ) of fixative containing $2 \%(\mathrm{w} / \mathrm{v}$ ) os- 
mium tetroxide, $0.8 \%(\mathrm{w} / \mathrm{v})$ potassium hexacyanoferrate $\left(\mathrm{K}_{4} \mathrm{Fe}(\mathrm{CN})_{6}\right)$ in $100 \mathrm{mM}$ cacodylate buffer at $\mathrm{pH} 7.0$ before exposing to final fixative for $1 \mathrm{hr}$ at room temperature.

After rinsing in buffer and washing with distilled water for 10 minutes of three times before dehydration. After dehydration in ethanol series at room temperature, embeddment in Spurr's low viscosity resin (Polyscience) and polymerization were carried out at $60^{\circ} \mathrm{C}$ for $24 \mathrm{hr}$. Ultrathin sections were made using Leica ultramicrotome (Ultracut E) and collected on formvar coated nickel grids (100 mesh). Sections were conventionally double stained with uranyl acetate and lead citrate before observation with JEOL 1200EX-II electron microscope operating at $80 \mathrm{kV}$.

\section{Results}

At the time of exine formation, the sporopollenin was began to be accumulated in-between exine and orbicular bodies accompanying tapetal PCD. The initiation of PCD was observed as the fusion of small vacuoles or vesicles. No inclusions except membraneous structure in the vacuoles or vesicles are visible at the time of vacuolar fusion, and the tapetal cytoplasm and ribosomes are still intact (Fig. 1).

Even cytoplasmic condensation has already processed in the tapetal cells, middle layer and endothecium are still intact. Low electron density and normal configuration of palstids are clearly observed. On the contrary, tapetal cytoplasm shows high electron density and that's because cell organelles could not be unidentified. Lamellar structure and lots of vacuoles are also observed in the tapetum (Fig. 2).

At the beginning of nuclear fragmentation, the contents of heterochromatin were increased, and nuclear membrane was observed irregular configuration(Fig. 2). Nuclear fragmentations (Fig. 3. arrows) are observed after darkening of cytoplasm. Small specks with high electron density are scattered in the nucleus and these thought to be fragments of nucleus. Lipid droplet (L) is still intact, but mitochondria (M) shows degenerated cristae. Vacuolar fusion is still very common in the cytoplasm.

Darkening of nucleus is observed at the time of vacuolar fusion. Internal structures are not identifiable because of high electro density in the nucleus. Small vacuoles are being fused at the periphery of nucleus to form large central vacuole, and cytoplasm is also being condensed (Fig. 4).

After nuclear fragmentation, cell organelles are being degenerated, and electron density of cytoplasm is high (Fig.
5). No cell organelles in the tapetal cells are identifiable after formation of exine (Fig. 6,7). At relatively late stage of PCD, lipid droplets are fused, and then it became irregular (Fig. 7).

No membranaceous structures are visible in the tapetal cells after complete degeneration of cytoplasm, comparing compressed cytoplasm of middle layer even it has high electron density (Fig. 8). Tapetal cell wall is partially degenerated. At last stage of PCD in tapetum, no cytoplasm and no intracellular structures were observed (Fig. 9,10). Large lipid droplets are observed between orbicular bodies. Orbicular bodies, surrounded with dark material called sporopollenin, are arranged in a curved linear row. Irregular or globular structure of undigested materials with very high electron density are observed between orbicular bodies (Fig. 10).

\section{Discussion}

Angiosperm tapetum is known to be amoeboid type and secretory type. In amoeboid type which is common in monocotyledons, developing microspores are surrounded by tapetal cytoplasm in the locule, and then supply nutrients to the developing microspore. At late stage of microsporogenesis, tapetal cells undergo degeneration called programmed cell death. On the contrary of the movement of tapetal cytoplasm to the locule in amoeboid type, no movement of the cells or cytoplasm occurr in the secretory type [15].

Tapetum was began to be degenerated after separation of microspore tetrads. During this processes, some specific structural changes such as collapse of cells, vacuolar development and thinning of cell walls were observed [34]. These changes are different from other types of PCD occurred in sclerogenesis, leaf senescence, differentiation of root cap cells and somatic embryogenesis [25].

If the tapetum degenerate too late or too early, abnormal pollen might be formed. Pollination and fertilization are also known to be affected by normal PCD of tapetal cells [34].

Ginseng tapetum is known as secretory type, and therefore tapetum degeneration is initiated at the time of sporopollenin accumulation (Fig. 1). This is thought to be a little delayed comparing other species of angiosperm. The beginning step of PCD was observed as vacuolar fusion, but ribosomes and other cytoplasmic structures are still intact (Fig. 1). Vacuolar or vesicular fusion in this study resemble the vacuolar vesicles in the coleoptile apoptotic cells which are 

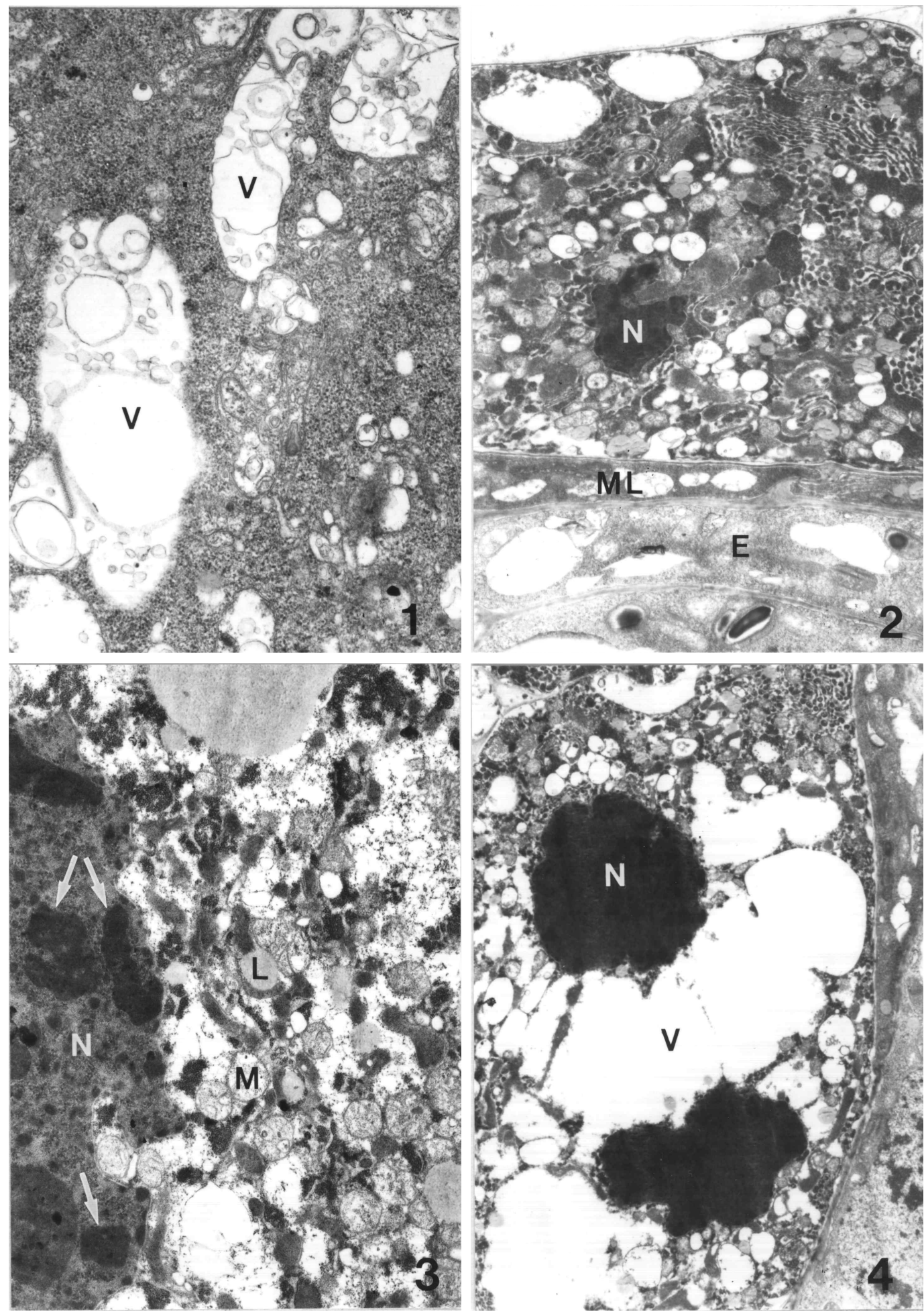

Fig. 1. Vacuolar fusions in the cytoplasm are the first indication of PCD in the tapetal cells. The cytoplasm is intact at this stage except small vesicles or vacuoles in the large vacuole $(\mathrm{V}) . \times 21,000$

Fig. 2. Condensation of cytoplasm and nuclear condensation occurred after initiation of PCD. Note the intact configuration of cytoplasm and cell organells in middle layer (ML) and endothecium (E). N:Nucleus $\times 7,300$

Fig. 3. Nuclear fragmentations(arrows) are clearly visible after beginning of PCD. Lipid droplet (L) is still intact, but mitochondria (M) shows degenerated cristae. x11,400

Fig. 4. Nuclear darkening at the time of vacuolar fusion $(\mathrm{V})$ is observed at the stage of nuclear fragmentation. $\times 4,700$ 

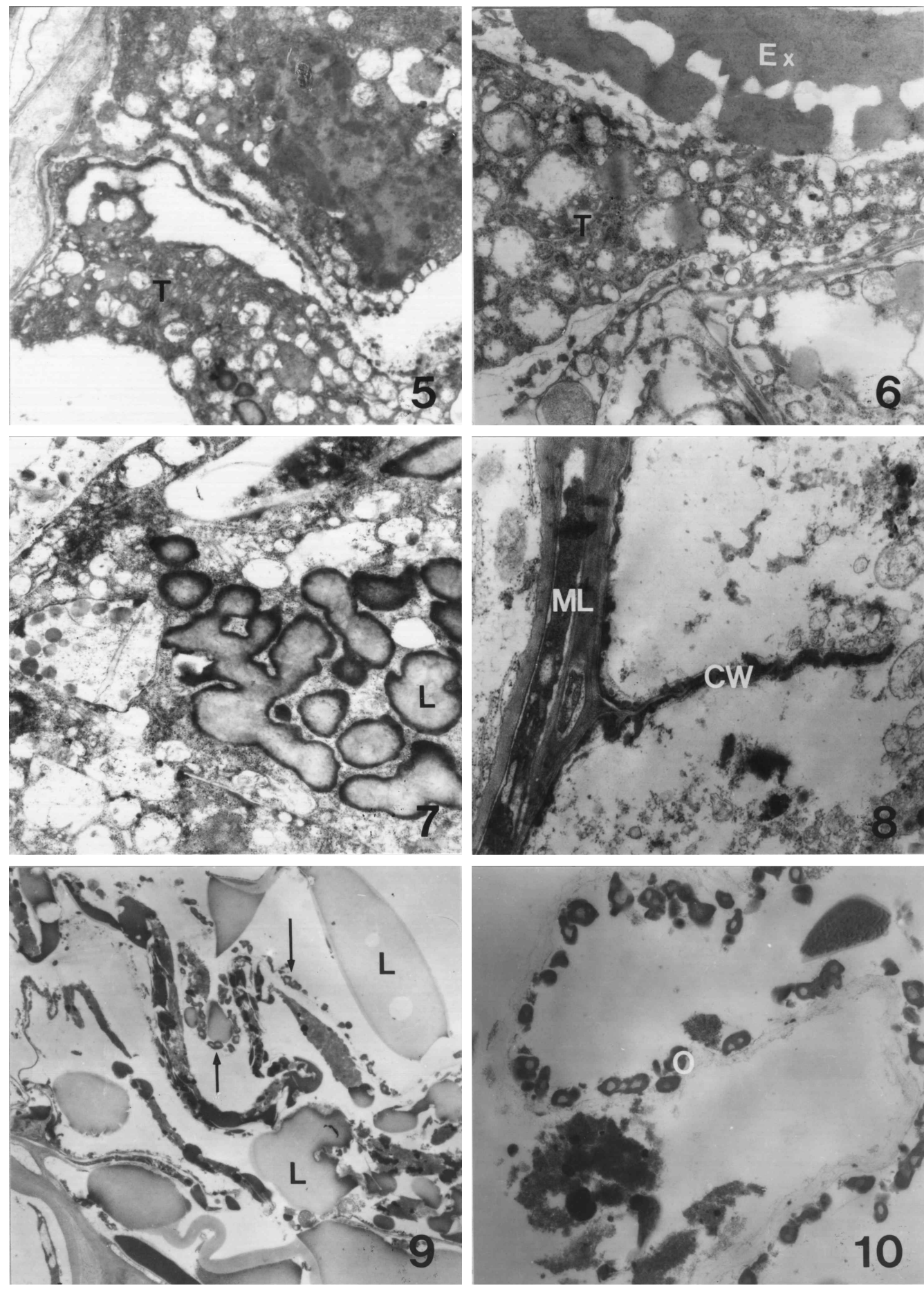

Fig. 5. Cytoplasmic condensations with unclear cell organelles in the tapetum(T). Vacuolation is being processed to evacuate cytoplasm. $\times 8,100$

Fig. 6. Mitochondrial degradations are occurred in all the cytoplasm of tapetum (T). Exine $(\mathrm{Ex})$ is already formed prior to tapetal PCD. $\times 11,100$

Fig. 7. Fusion of cytoplasmic lipid droplets (L) are observed at the relatively late stage. Note the irregular shape of fused lipid droplets. $\times 15,600$

Fig. 8. Partial remaining of cell wall (CW) between tapetal cell, compressed cells in middle layer (ML) indicate the late step of PCD. $\times 16,000$

Fig. 9. Low electron density of lipid droplets (L) and orbicular bodies (arrows) shows last stage of tapetal PCD. $\times 6,400$

Fig. 10. Orbicular bodies $(\mathrm{O})$ are lined up without changing their shape after completely degenerated cytoplasm. $\times 15,000$ 
specific for the apoptotic plant cells. Condensation of cytoplasm, formation of myelin-like structures, fragmentation of cytoplasm, appearance of vacuolar vesicles, condensation and margination of chromatin in the nucleus, and internucleosomal fragmentation of nuclear DNA are the ultrastructural features of apoptosis in the wheat leaf [38].

The early stages of the induction of this PCD process consisted in cell shrinkage and chromatin condensation at the periphery of the nucleus in hydrogen peroxide treated cells [14]. A special organelle called ricinosome is a novel organelle, found so far exclusively in the senescencing endosperm of germinating castor beans endosperm cells [10]. Electron microscopic studies suggested that ricinosomes are originated from the endoplasmic reticulum [29], and they delivered large amounts of cysteine protease to digest storage material at early stage of PCD [10]. Both of the cell shrinkage and ricinosome-like structures are not found in this study.

High electron density of tapetal cytoplasm and fragmented nucleus were observed in this study. Characteristically, small specks are scattered in-between the fragmented chromatin (Fig. 3). High density of electrons in the degenerating nucleus is another findings at middle stage of tapetal PCD of ginseng (Fig. 4).

Nuclear DNA fragmentation was first observed from the third day after germination in the endosperm cells adjacent to the cotyledons of caster bean germinating seed [28]. PCD of barley aleurone layers occurs as highly vacuolation and abrupt loss of plasma membrane integrity. This cell death does not follow the hallmarks of apoptotic pathway including internucleosomal DNA cleavage, plasma membrane and nuclear blebbing and formation of apoptotic bodies. PCD in barley aleurone cells is accompanied by the enzyme accumulation and the loss of organelles as a result of cellular autolysis [7]. Autolytic degradation of the cytoplasm is accompanied by budding-like segmentation of the nucleus. Nuclear DNA undergoes fragmentation into both large fragments of about $50 \mathrm{~kb}$ and multiples of approximately $180 \mathrm{bp}$ [8].

Cell organelles such as mitochondria, plastids, and ER are began to be degenerated after exine formation (Fig. 6,7). Exine is the outermost pollen wall to protect itself from mechanical and chemical damages. Tapetal cytoplasm is no longer necessary to developing pollen, and therefore this was thought to be disintegrated at late stage of PCD.

Cytoplasm and cell organelles disappeared prior to vacuolar rupture in spruce. The protoplasm then disappears, leaving a cellular corpse represented by only the cell wall.
This pathway of cell dismantling suggests overlapping of apoptotic and autophagic types of PCD during somatic embryogenesis in Norway spruce [8].

The mitochondrial pathway is regarded as a conventional route of some types of PCD in animal cells where specific signals cause the release of cytochrome $\mathrm{c}$ from mitochondria to trigger a proteolytic cascade involving caspases. However, plant cells lack canonical caspases, therefore the role of caspases in programmed cell death in plant cells is not obvious. Only limited evidence has been obtained about cytochrome $\mathrm{c}$ to trigger the PCD in plant organ differentiation. Prior to execution of cellular autolysis initiated by the rupture of the large central vacuole to release sequestered hydrolases, mitochondria adopt a definable morphology, the inner membrane depolarizes prior to death, and cytochrome $\mathrm{c}$ is released from mitochondria [37].

Diverse orientations of plant PCDs have been sugested because of the absence of the hallmarks of animal PCDs such as DNA laddering, formation of apoptotic bodies, a cell-death-specific nuclease and biochemical machinery such as caspase. And the resistance of cell wall against phagocytotic enzymes is another factor of different types of PCD. Large gaps in the understanding of plant cell death have prompted speculative inferences and comparisons with other cell death mechanisms [26].

Tapetal cell wall, in this study, is the last degenerating components (Fig. 9,10), because of the resistance of cellulose texture against vacuolar enzymes. After complete dissolution of cell organelles, the orbicular bodies are remained along the undigested cell wall of middle layer. Orbicular bodies were surrounded by sporopollenin to protect itself from chemical and ultraviolet light [4]. Even after dehiscence of anther and discharge of pollen grain for pollination, orbicular bodies may function to protect remaining pollen grains on the anther wall. Therefore they should be remained on the anther wall even after programmed cell death of tapetum.

\section{Acknowledgement}

This research was supported in part by a grant from Kosin University.

\section{References}

1. Arunika, G., D. M. Pearce, M. B. Jackson, C. R. Hawes, and 
D. E. Evans. 2001. Characterization of programmed cell death during aerenchyma formation induced by ethylene or hypoxia in toots of maize. Planta 212, 205-214.

2. Bethke, P. C. and R. L Jones. 2001. Cell death of barley aleurone protoplasts is mediated by reactive oxygen species. Plant J. 25, 19-29.

3. Chen, H. M., J. Zhou, and Y. R. Dai. 2000. Cleavage of lamin-like proteins in in vivo and in vitro apoptosis of tobacco protoplasts induced by heat shock. FEBS Lett. 480, 165-168.

4. Danon, A. and P. Gallois. 1998. UV-C radiation induces apoptotic-like changes in Arabidopsis thaliana. FEBS Lett. 437, 131-136.

5. DeJong, A. J., F. A. Hoeberichts, E. T. Yakimova, E. Maximova, and E. J. Woltering. 2000. Chemical-induced apoptotic cell death in tomato cells: involvement of caspase-like proteases. Planta 211, 656-662.

6. Drew, M. C., C. J. He, and P. W. Morgan. 2000. Programmed cell death and aerenchyma formation in roots. Trends Plant Sci. 5, 123-127.

7. Fath, A., P. Bethke, L. J, Meza-Romero, and R. Jones. 2000. Programmed cell death in cereal aleurone. Plant Mol. Biol. 44, 255-266

8. Filonova, L. H., P. V. Bozhkov, V. B. Brukhin, G. Daniel, B. Zhivotovsky, and S. Arnold. 2000. Two waves of programmed cell death occur during formation and development of somatic embryos in the gymnosperm, Norway spruce. J. Cell Sci. 113, 4399-4411.

9. Fukuda, H. 2000. Programmed cell death of tracheary elements as a paradigm in plants. Plant Mol. Biol. 44, 245-253.

10. Gietl, C. and M. Schmid. 2001. Ricinosomes: an organelle for developmentally regulated programmed cell death in senescing plant tissues. Naturwissenschaften 88, 49-58.

11. Hansen, G. 2000. Evidence for Agrobacteriuminduced apoptosis in maize cells. Mol. Plant Microbe. Interact 13, 649-657.

12. Hermann, P. M. and B. F. Palser. 2000. Stamen development in the Ericaceae. I. Anther wall, microsporogenesis, inversion, and appendages. Am J. Bot. 87, 934-957.

13. Hernould, M., E. Zabaleta, J. P. Carde, S. Litvak, A. Araya, and A. Mouras. 1998. Impairment of tapetum and mitochondria in engineered male-sterile tobacco plants. Plant Mol. Biol. 36, 499-508.

14. Houot, V., P. Etienne, A. S. Petitot, S. Barbier, J. P. Blein, and L. Suty. 2001. Hydrogen peroxide induces programmed cell death features in cultured tobacco BY-2 cells, in a dose-dependent manner. J. Exp. Bot. 52, 1721-1730.

15. Jeong, B. K. 2005. Fine Structural Study of Pollen Wall Development at Late Stage of Microsporogenesis in Panax ginseng. Korean J. Electron Microscopy 35, 263-272.

16. Jones, A. M. and J. L. Dangl. 1996. Logjam at styx:programmed cell death in plants. Trends Plant Sci. 1, 114-119.

17. Katsuhara, M. 1997. Apoptosis-like cell death in barley roots under salt stress. Plant and Cell Physiology 38, 1091-1093.

18. Koukalova, B, A. Kovarik, J. Fajkus, and J. Siroky. 1997. Chromatin fragmentation associated with apoptotic changes in tobacco cells exposed to cold stress. FEBS Lett. 414, 289-292.
19. Kreunen, S. S. and J. M. Osborn. 1999. Pollen and anther development in Nelumbo (Nelumbonaceae). Am J. Bot. 86, 1662-1676.

20. MacCarrone, M., G. Zadelhoff, G. A. Veldink, J. F. Vliegenthart, and A. Finazzi-Agro. 2000. Early activation of lipoxygenase in lentil (Lens culinaris) root protoplasts by oxidative stress induces programmed cell death. Eur. J. Biochem 267, 5078-5084.

21. Mittler, R. and E. Lam. 1997. Characterization of nuclease activities and DNA fragmentation induced upon hypersensitive response cell death and mechanical stress. Plant Mol. Biol. 34, 209-221.

22. Pedroso, M. C. and D. Durzan. 1999. Detection of apoptosis in chloroplasts and nuclei in different gravitational environments. J. Gravit. Physiol. 6, 19-20.

23. Pedroso, M. C. and D. Durzan. 2000. Effect of different gravity environments on DNA fragmentation and cell death in Kalanchoe leaves. Ann. Bot. 86, 983-994.

24. Penet, L, S. Nadot, A. Remaster, A. Forchioni, L. Dreyer, and P. H. Gouyon. 2005. Multiple developmental pathways leading to a single morph: monosulcate pollen (examples from the Asparagales). Ann. Bot. 95, 331-343.

25. Pennel, I. R. and C. Lamb. 1997. Programmed cell death in plants. Plant Cells 9, 1157-1168.

26. Ranganath, R. M. and N. R. Nagashree. 2001. Role of programmed cell death in development. Int. Rev. Cytol. 202, 159-242.

27. Rubinstein, B. 2000. Regulation of cell death in flower petals. Plant Mol. Biol. 44, 303-318.

28. Schmid, M., D. Simpson, and C. Gietl. 1999. Programmed cell death in castor bean endosperm is associated with the accumulation and release of a cysteine endopeptidase from ricinosomes. Proc. Natl. Acad Sci. 96, 14159-14164.

29. Schmid, M., D. J. Simpson, H. Sarioglu, F. Lottspeich, and C. Gietl. 2001. The ricinosomes of senescing plant tissue bud from the endoplasmic reticulum. Proc. Natl. Acad Sci. 98, 5353-5358.

30. Stein, J. C. and G. Hansen. 1999. Mannose induces an endonuclease responsible for DNA laddering in plant cells. Plant Physiology 121, 71-80.

31. Ting, J. T., S. S. Wu, C. Ratnayake, and A. H. Huang. 1998. Constituents of the tapetosomes and elaioplasts in Brassica campestris tapetum and their degradation and retention during microsporogenesis. Plant J. 16, 541-551.

32. Verellen, J., E. Smets, and S. Huysmans. 2004. The remarkable genus Coptosapelta (Rubiaceae) : pollen and orbicule morphology and systematic implications. J. Plant Res. 117, 57-68.

33. Worrall, D., D. L. Hird, R. Hodge, W. Paul, J. Draper, and R. Scott. 1992. Premature dissolution of the microsporocyte callose wall causes male sterility in transgenic tobacco. Plant Cell 4, 759-771.

34. Wu, H. M. and A. Y. Cheun. 2000. Programmed cell death in plant reproduction. Plant Mol. Biol. 44, 267-281.

35. Xu, Y. and M. R. Hanson. 2000. Programmed cell death during pollination-induced petal senescence in petunia. Plant 
Physiol. 122, 1323-1333.

36. Young, T. E. and D. R. Gallie. 2000. Programmed cell death during endosperm development. Plant Mol. Biol. 44, 283301.

37. Yu, X. H., T. D. Perdue, Y. M. Heimer, and A. M. Jones. 2002. Mitochondrial involvement in tracheary element programmed cell death. Cell Death Differ. 9, 189-198.

38. Zamyatnina, V. A., L. E. Bakeeva, N. I. Aleksandrushkina, and B. F. Vanyushin. 2002. Apoptosis in the initial leaf of etiolated wheat seedlings: Influence of the antioxidant ionol (BHT) and peroxides. Biochemistry 67, 212-221.

39. Zhang, C., F. C. Guinel, and B. A. Moffatt. 2002. A comparative ultrastructural study of pollen development in Arabidopsis thaliana ecotype Columbia and male-sterile mutant apt1-3. Protoplasma 219, 59-71.

\section{초록 : 인삼 융단조직의 프로그램 세포사에 관한 미세구조적 연구}

\section{정 병 갑*}

(고신대학교 생명과학부)

융단조직은 약실 내에서 발달하는 소포자에 영양분을 공급하고 퇴화되는 조직으로써, 소포자 4 분자 시기에 최대 로 발달하고 화분벽에 포분질에 축적된 후 프로그램 세포사가 일어남으로써 세포가 죽게 되고 융단조직 전체가 퇴화된다. 액포가 융합되므로써 프로그램 세포사가 시작되고 세포질응축, 핵질 분절 등이 뒤따라 일어난다. 지질 덩어리는 비교적 늦은 시기에 퇴화되며 orbicular body는 가장 늦게까지 남아 있게 된다. 융단세포의 프로그램세포 사 전 과정 중에서 세포벽은 액포에서 기원하는 가수분해 효소에 비교적 안정적이므로 가장 늦게 퇴화되는 것으로 확인되었다. 